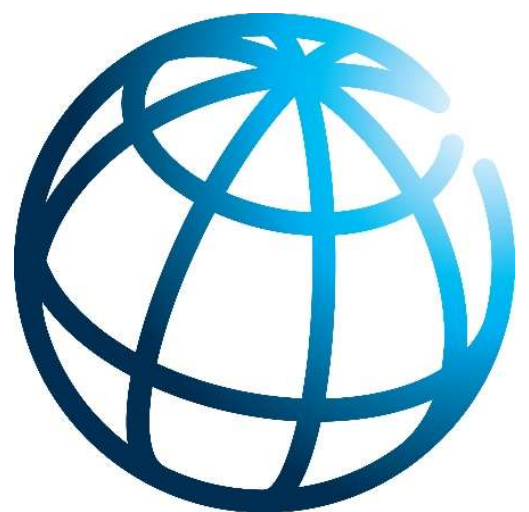

\title{
THE WORLD BANK SERBIA
}

\section{Country Economic Memorandum Serbia's New Growth Agenda}

\author{
Mariya Brussevich and Shawn W. Tan \\ November 28, 2019
}




\section{Contents}

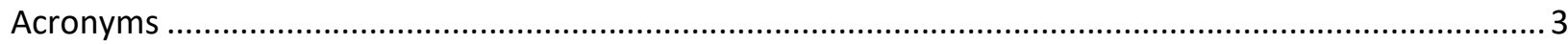

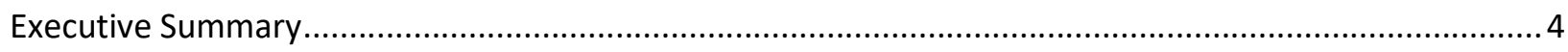

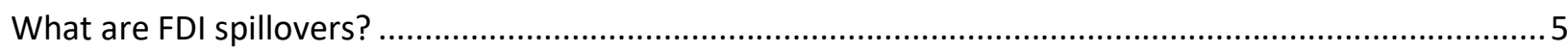

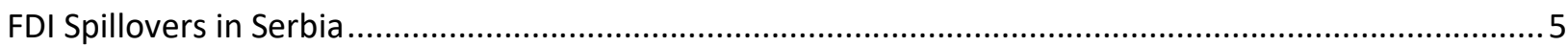

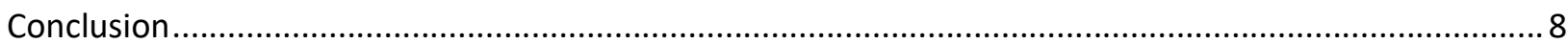

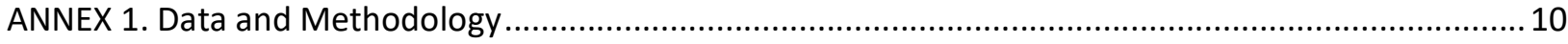

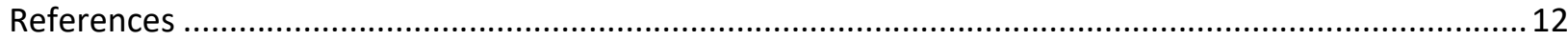




$\begin{array}{ll}\text { Acronyms } & \\ \text { BRA } & \text { Business Registries Agency } \\ \text { FDI } & \text { Foreign Direct Investment } \\ \text { HHI } & \text { Herfindahl-Hirschman Index } \\ \text { IO } & \text { Input-Output } \\ \text { NACE } & \text { Statistical classification of economic activities in the European Community } \\ & \text { (Nomenclature statistique des activités économiques dans la Communauté européenne) } \\ \text { OECD } & \text { Organisation for Economic Co-operation and Development } \\ \text { TFP } & \text { Total Factor Productivity }\end{array}$




\section{Executive Summary}

This note examines the relationship between the presence of foreign firms and total factor productivity (TFP) growth of domestic firms (called "FDI-Foreign Direct Investment--spillovers") in Serbia over the period of 2005-16. The analysis finds evidence of FDI spillovers in Serbia. Domestic firms on average enjoy higher productivity because of the presence of FDI firms in the economy. Moreover, domestic firms that supply to FDI firms or are located in the same industry as FDI firms, enjoy higher productivity. This presumably stems from technology transfer, higher quality standards, or higher competition. However, productivity of domestic firms sourcing from industries with a large share of FDI firms find their productivity reduced, likely due to markups by foreign firms.

The effect of FDI on productivity of domestic firms also varies by firm size and industry. Small firms benefit more from spillovers associated with backward linkages (when they supply to an FDI firm) but are worse off with more horizontal FDI (when they compete with FDI firms in the same industry). Firms in high-tech industries benefit more from horizontal and backward FDI spillovers, but firms in low-tech industries experience no effect. Lastly, firms in the transport manufacturing industry do not enjoy any FDI spillovers from foreign firms in their industry.

The government therefore can do more to ensure that domestic firms, especially small and medium firms and those in low-tech industries, benefit from FDI through entrepreneurship and innovation programs. Such programs include export readiness and export coaching programs, which can improve the export performance of domestic firms and strengthen linkages with foreign firms in the country; supplier linkages programs, which can provide technical assistance to domestic firms and information to foreign firms about potential domestic suppliers; and finally, programs targeted toward increasing innovation and technology adoption on the part of domestic firms, which can help them to achieve high enough productivity levels to be able to absorb FDI spillovers. 


\section{What are FDI spillovers?}

Foreign direct investment (FDI) is an important growth channel for many developing countries. FDI brings financing, advanced technology, and know-how to host countries. Serbia has been successful in attracting FDI in the last decade and has been eager to provide tax and investment incentives. A recent World Bank study (2017) evaluated the Serbian investment incentive program and found that the incentive attracted foreign firms to create almost 12,000 jobs between $2006-15$. While job creation is a critical policy objective, it is also important that the productivity levels of domestic firms increase with exposure to foreign firms. This is the spillover effect. Using the rich dataset provided by the Business Registries Agency (BRA) and combined with data provided by Serbian Customs, this paper seeks to present empirical evidence of FDI spillovers, in other words, to answer the question: "Are domestic firms in the Serbian economy more productive due to the increased presence of foreign firms?"

Research and policy studies have established the presence of spillovers from FDI on host countries. ${ }^{1}$ These studies show that FDI spillovers usually happen through buyer-seller linkages across different industries. ${ }^{2}$ Foreign firms have no incentive to share their technology with local competitors in the same industry. Instead, the linkages between the foreign buyers and domestic sellers are what matter: domestic firms that sell to industries with more foreign firms are, on average, more likely to enjoy spillover benefits.

The FDI spillovers can occur through three channels. First, foreign firms that source locally can increase demand for domestic suppliers. As foreign firms often require higher standards of intermediate inputs, domestic firms competing to sell to them increase their product quality and productivity. Moreover, foreign buyers will often provide training and technological support to their domestic suppliers to ensure quality upgrades. These effects are captured by the backward linkages between foreign and domestic firms. Second, domestic firms can hire workers moving from foreign firms, or domestic workers at foreign firms can leave to set up businesses that are often connected to the foreign firms. Third, domestic firms can learn new management practices and operating processes from foreign firms through demonstration effects. Positive spillovers, however, are not guaranteed, as foreign firms can also impose negative spillovers on domestic firms through labor and product competition.

\section{FDI Spillovers in Serbia}

There are three methods to measure the presence and impact of FDI in a given industry, based on the relationships between the foreign and domestic firms: horizontal, backward, and forward FDI (from the perspective of the FDI firm) (Figure 1). Horizontal FDI spillovers measure the impact of the presence of foreign firms on the productivity of domestic firms in the same industry. Backward FDI spillovers measure effects of the share of foreign firms in industries supplied by domestic firms. Forward FDI spillovers measure the impact of the presence of foreign firms on productivity in the industries from which domestic firms purchase.

\footnotetext{
${ }^{1}$ See Harrison and Rodriguez-Clare (2010) for a summary of the literature.

${ }^{2}$ See for example, the seminal study by Javorcik (2004) on the presence of spillovers from domestic firms selling to foreign firms in Lithuania.
} 
Figure 1: Definitions of FDI spillovers

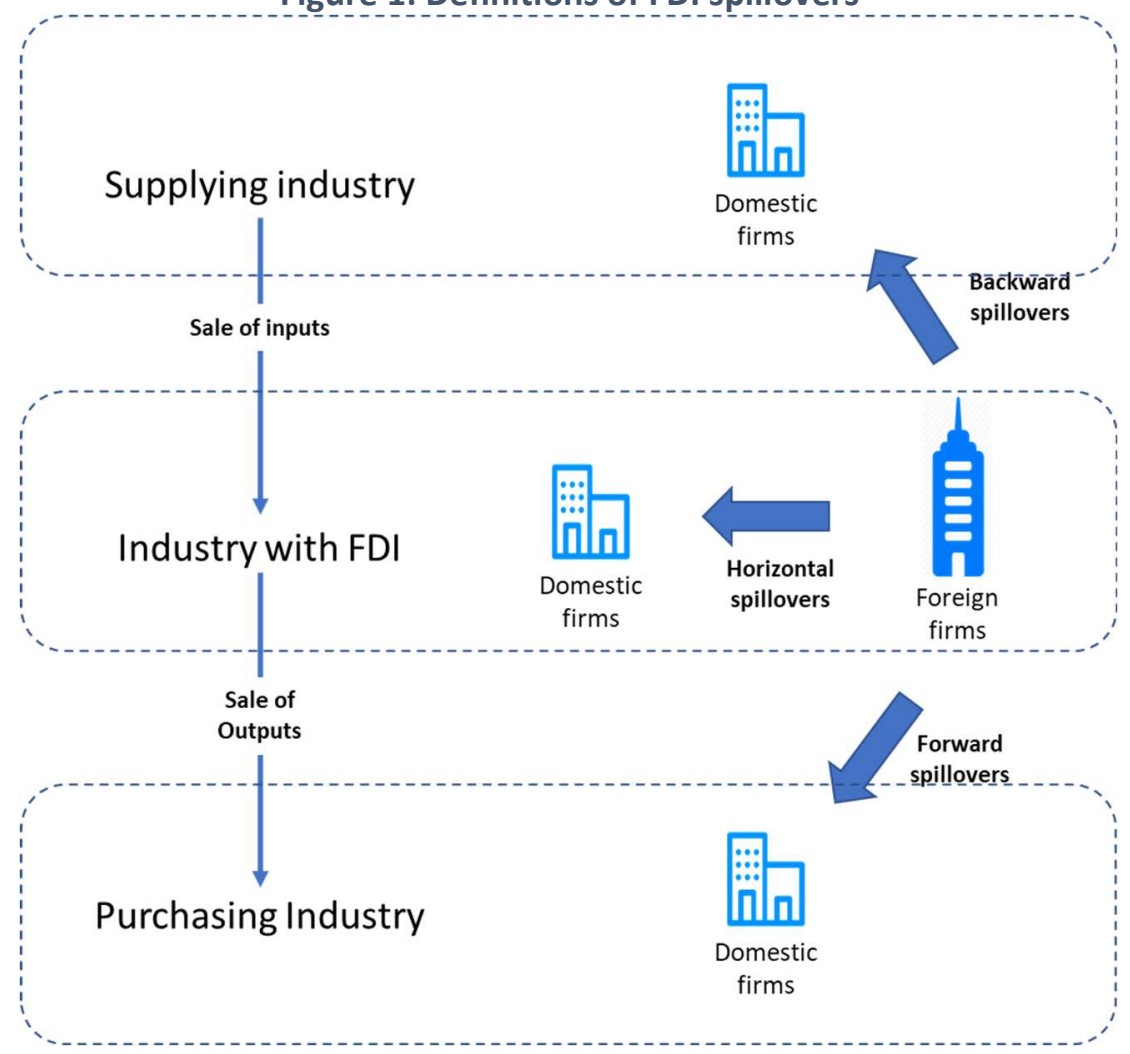

Source: Brussevich and Tan, 2019.

The results presented in Table 1 provide evidence of horizontal, backward, and forward FDI spillovers in Serbia. Increased horizontal and backward FDI spillovers are associated with higher TFP growth of domestic firms, while increased forward FDI spillovers are associated with lower TFP growth. Namely, an increase of one percentage point in horizontal spillovers can increase TFP growth of domestic firms by 0.9 percent, and an increase of one percentage point in backward spillovers can increase TFP growth by 0.2 percent. ${ }^{3}$ In contrast, an increase of one percentage point in forward spillovers can decrease TFP growth by 0.5 percent. The cumulative impact of a one percentage point increase in all spillover variables on TFP is positive.

There are three noteworthy regression results. First, the positive relationship between backward FDI spillovers and TFP growth in Serbia is consistent with the economic literature. This relationship is precisely the justification for governments (including in Serbia) to provide investment incentives to attract FDI. Second, horizontal FDI spillovers are positively related with TFP growth, which is unusual given that many other studies do not find evidence of this. ${ }^{4}$ This suggests that foreign firms have an incentive to transfer knowledge of technology to firms in their industry and do not view them as competitors. ${ }^{5}$ Third, forward

\footnotetext{
${ }^{3}$ Note that the regression is log-linear, so the coefficient interpretations are technically interpreted according to the formula: [exp(coefficient)-1].

${ }^{4}$ See Harrison and Rodriguez-Clare (2010).

${ }^{5}$ An alternative explanation may be that workers in these foreign firms are leaving to open new firms, which use the knowledge and technology learnt in the foreign firm. The analysis removed this possible explanation by focusing on firms already in the market and excluded new entrant firms.
} 
FDI spillovers are negatively related to TFP growth, ${ }^{6}$ which suggests that domestic firms buying foreign firms are worse off, as they may face higher prices or inferior buying conditions, thus reducing their productivity. ${ }^{7}$ The available data is not adequate to fully examine this hypothesis.

Table 1: Regression results for full sample (domestic firms) and subsamples by firm size.

\begin{tabular}{|c|c|c|c|c|}
\hline & \multirow[t]{2}{*}{ Full Sample } & \multicolumn{3}{|c|}{ Subsamples by firm size } \\
\hline & & Small & Medium & Large \\
\hline \multirow[t]{2}{*}{ Horizontal } & $0.642^{*}$ & $-0.105^{* *}$ & -0.075 & 0.184 \\
\hline & $(0.288)$ & $(0.057)$ & $(0.080)$ & $(0.132)$ \\
\hline \multirow[t]{2}{*}{ Backward } & $0.176^{*}$ & $0.235^{*}$ & $0.130^{*}$ & -0.030 \\
\hline & $(0.080)$ & $(0.049)$ & $(0.080)$ & $(0.159)$ \\
\hline \multirow[t]{2}{*}{ Forward } & $-0.613 * * *$ & $-0.380 * *$ & $-0.476 * * *$ & $-0.750 * * *$ \\
\hline & $(0.121)$ & $(0.071)$ & $(0.137)$ & $(0.262)$ \\
\hline \multirow[t]{2}{*}{$\mathrm{HHI}^{8}$} & $-0.035 * * *$ & 0.002 & $0.013^{*}$ & 0.000 \\
\hline & $(0.012)$ & $(0.002)$ & $(0.005)$ & $(0.003)$ \\
\hline \multirow[t]{2}{*}{$\log ($ Demand) } & $0.308 * *$ & 0.042 & 0.021 & $0.255^{*}$ \\
\hline & $(0.090)$ & $(0.026)$ & $(0.047)$ & $(0.108)$ \\
\hline \multirow[t]{2}{*}{ Constant } & $-0.108^{* *}$ & $-0.038 * * *$ & 0.007 & $-0.028^{*}$ \\
\hline & $(0.029)$ & $(0.004)$ & $(0.007)$ & $(0.016)$ \\
\hline $\mathrm{N}$ & 36200 & 31096 & 7761 & 2010 \\
\hline \multicolumn{5}{|c|}{$\begin{array}{l}\text { Clustered standard errors in parentheses. The dependent variable is log TFP and both dependent and } \\
\text { independent variables are expressed in first differences as described in the equation above. The } \\
\text { regressions contain industry (NACE) }{ }^{9} x \text { year and region } x \text { year fixed effects. }{ }^{*} p<0.05,{ }^{* *} p<0.01 \text {, }{ }^{* * *} p \\
<0.001 \text {. }\end{array}$} \\
\hline
\end{tabular}

The effects of FDI spillovers vary by firm size. The FDI spillovers are strongest for small and medium firms but differ in terms of signs from the main results (Table 1). Horizontal spillovers are negatively associated with TFP growth for small firms, indicating that they lose out when there are more foreign firms in their industry. There is no evidence of horizontal spillovers for medium and large firms. Backward spillovers are still positively associated with TFP growth for small and medium firms, but not for large firms. Horizontal spillovers are negatively associated with TFP growth for all firm sizes.

The effects of FDI spillovers also vary by industry (Table 2). There are different spillover effects depending on whether the firms are in a high or low technology industry. The industries are classified according to the Organisation for Economic Co-operation and Development (OECD) classification of high, medium-high, medium-low, and low technology. ${ }^{10}$ Firms in high-tech industries are positively affected by horizontal and backward FDI, while firms in medium-tech industries are positively affected by backward FDI but

\footnotetext{
${ }^{6}$ The evidence is mixed on the relationship between forward linkages and firm productivity. Javorcik (2004) observed a negative relationship, while Harrison and Rodríguez-Clare (2010) find in their survey that other studies show a positive relationship.

${ }^{7}$ The TFP calculated in the empirical exercise is revenue productivity, so it consists of profitability and physical productivity. The lack of firm-level prices prevents any calculations of physical productivity.

${ }^{8}$ Herfindahl-Hirschman Index ( $\left.\mathrm{HHI}\right)$, a measure of market concentration.

${ }^{9}$ Statistical classification of economic activities in the European Community (NACE--Nomenclature statistique des activités économiques dans la Communauté européenne).

${ }^{10}$ See https://www.oecd.org/sti/ind/48350231.pdf.
} 
negatively affected by forward FDI. The strong evidence of positive FDI spillovers for firms in high-tech industries supports the hypothesis that firms require a certain level of absorptive capacity to benefit from the knowledge or technology spillovers from foreign firms. Given the prominence of FDI in the transport manufacturing industry, ${ }^{11}$ the analysis also examines if there are heterogenous effects of FDI spillovers for firms in that industry. There is no evidence that domestic firms in the transport manufacturing industry are benefiting from foreign firms in their industry (horizontal FDI). However, positive spillover effects are present for firms in other manufacturing industries supplying to foreign firms (backward FDI).

Table 2: Regression results for subsamples by technology levels and industry (transport manufacturing)

\begin{tabular}{|c|c|c|c|c|c|c|}
\hline & \multicolumn{4}{|c|}{ Subsamples by Industry's Technology Levels } & \multicolumn{2}{|c|}{ Subsamples by industry } \\
\hline & High & Med-high & Med-low & Low & $\begin{array}{c}\text { Transport } \\
\text { Manu. }\end{array}$ & $\begin{array}{l}\text { Rest of } \\
\text { Manu. }\end{array}$ \\
\hline \multirow[t]{2}{*}{ Horizontal } & $0.048^{*}$ & -0.074 & -0.125 & -0.017 & -0.346 & -0.042 \\
\hline & $(0.001)$ & $(0.055)$ & $(0.085)$ & $(0.047)$ & $(0.063)$ & $(0.040)$ \\
\hline \multirow[t]{2}{*}{ Backward } & $0.748^{*}$ & $0.388^{*}$ & 0.163 & 0.141 & 0.420 & $0.170^{*}$ \\
\hline & $(0.034)$ & $(0.110)$ & $(0.124)$ & $(0.094)$ & $(0.070)$ & $(0.070)$ \\
\hline \multirow[t]{2}{*}{ Forward } & 0.170 & $-0.556^{*}$ & -0.406 & $-0.429 *$ & $-0.532 * *$ & $-0.435 * * *$ \\
\hline & $(0.025)$ & $(0.208)$ & $(0.179)$ & $(0.142)$ & $(0.003)$ & (0.104) \\
\hline \multirow[t]{2}{*}{$\mathrm{HHI}$} & 0.000 & 0.007 & 0.002 & 0.001 & 0.004 & 0.004 \\
\hline & $(0.000)$ & $(0.003)$ & $(0.006)$ & $(0.003)$ & $(0.001)$ & $(0.003)$ \\
\hline \multirow{2}{*}{$\begin{array}{l}\text { Log } \\
\text { (Demand) }\end{array}$} & $-0.022^{*}$ & 0.055 & 0.086 & 0.032 & $0.192^{*}$ & 0.045 \\
\hline & $(0.000)$ & $(0.080)$ & $(0.047)$ & $(0.064)$ & $(0.013)$ & $(0.031)$ \\
\hline \multirow[t]{2}{*}{ Constant } & $-0.036 * *$ & -0.025 & $-0.052^{* * *}$ & $-0.016^{*}$ & $-0.075^{*}$ & $-0.027^{* * *}$ \\
\hline & $(0.000)$ & $(0.012)$ & $(0.005)$ & $(0.005)$ & $(0.005)$ & $(0.003)$ \\
\hline$N$ & 1974 & 6345 & 11633 & 20882 & 1137 & 39712 \\
\hline
\end{tabular}

\section{Conclusion}

There is evidence of FDI spillovers in Serbia. The TFP growth of domestic firms are positively associated with more horizontal and backward FDI, but negatively associated with more forward FDI. While the FDI spillovers may have different effects, a one percentage point in three FDI spillover measurements will have a cumulative positive effect on TFP of domestic firms. The positive effect of FDI offers justification for the government's FDI attraction programs, as foreign firms provide knowledge and technology spillovers to domestic firms. However, the effect of FDI varies by firm size and industry. Small firms benefit more from backward spillovers but are harmed by horizontal spillovers, unlike their medium and large size counterparts. Firms in high-tech industries also benefit more from horizontal and backward FDI spillovers, but firms in low-tech industries see no effect. This supports the need for firms to have a certain

\footnotetext{
${ }^{11}$ The car manufacturer Fiat is the main investor in the transport manufacturing sector in Serbia. It made heavy investments in Serbia during the period of analysis.
} 
level of absorptive capacity to benefit from FDI spillovers. Lastly, firms in the transport manufacturing industry do not enjoy any FDI spillovers from foreign firms in their industry.

Taken together, the evidence suggests that the government can do more to ensure that domestic firms, especially small and medium firms and those in low-tech industries, benefit from FDI through entrepreneurship and innovation programs. Such programs can include export readiness and export coaching programs, which will improve the export performance of domestic firms and strengthen linkages with foreign firms in the country. In addition, supplier linkages programs can provide technical assistance to domestic firms and information to foreign firms about potential domestic suppliers. Finally, programs targeted toward increasing innovation and technology adoption on the part of domestic firms can help them achieve high enough productivity levels to be able to absorb FDI spillovers. 


\section{ANNEX 1. Data and Methodology}

The note bases the analysis on a unique combination of two micro-level datasets: firm-level financial information from the Serbian Business Registry and transaction-level customs data from Serbian Customs for 2006-15. Business registry data contain information on a firm's balance sheet, age, and ownership status, which can be linked to the customs transaction data that contain details on the firm's imports and exports and corresponding countries of origin and destination. In addition to the standard firm-level variables, the dataset contains information on (i) amount of raw materials that are imported or sourced domestically; (ii) amount of sales that are exported or sold domestically; and (iii) geographic location of firms at the municipal level.

These data features allow us to examine firms' linkages to foreign and domestic markets in finer detail at a disaggregated geographical level. The existing literature on FDI spillovers does not take into account the foreign firms' domestic sourcing of intermediate inputs (or vertical linkages with the domestic economy), which creates the assumption that the foreign firms will have an equal productivity effect on domestic firms. The data allow a relaxation of this assumption and thus enable the study of differential impacts (depending on the vertical linkages of the foreign firms) of FDI spillovers at both the industry and regional level.

The analysis examines the presence of FDI spillovers in a regression framework by estimating the impact of FDI presence in the industries on the domestic firms' productivity levels. Ideally, the analysis would use firm-level transactions to identify actual linkages between domestic firms and foreign firms, but this information is rarely available. ${ }^{12}$ The next best alternative is to combine firm data with industry-toindustry linkages measured by the national Input-Output (IO) tables. Serbia does not have a national IO table, ${ }^{13}$ so the analysis uses the US IO tables. The US IO table is the most disaggregated IO table available (with over 300 industries, instead of the usual 50+ industries) and is commonly used in the literature as a proxy 10 table when one is unavailable for the country. Productivity is measured as TFP according to Ackerberg et al. (2015).

There are three methods to measure the presence of FDI in the industries based on the relationships between the foreign and domestic firms: horizontal, backward, and forward FDI. Horizontal FDI measures the presence of foreign firms in terms of output share in the same industry as the domestic firm. Backward FDI represents the share of foreign firms in the industries that are supplied by domestic firms. Forward FDI measures the presence of foreign firms in the industries that domestic firms purchase from. It should be noted that backward and forward FDI are from the perspective of the foreign firms.

The empirical specification relates domestic firms' productivity levels to horizontal, backward, and forward linkages of domestic and foreign firms:

\footnotetext{
12 There are some studies that are starting to use firm-level transaction data to evaluate firm linkages. See Bernard and others (2018) for a summary.

${ }^{13}$ Serbia is currently preparing an input-output table. This input-output table may not be suitable as it will not cover the time period of the analysis and may not have the necessary level of disaggregation in industries.
} 


$$
\begin{aligned}
& \Delta \log Y_{i j r t}=\alpha+\beta_{1} \Delta \text { Horizontal }_{\text {jrt }}+\beta_{2} \text { Backward }_{j r t}+\beta_{3} \text { Forward }_{\text {jrt }} \\
& +\beta_{4} \Delta \log \text { Demand }_{j t}+\beta_{5} H H I_{j t}+\gamma_{j t}+\sigma_{r t}+\varepsilon_{i j r t}
\end{aligned}
$$

$\Delta \log Y_{i j r t}$ is a change from year t-1 to $\mathrm{t}$ in firm i's productivity (in logs) in industry $j$ and region $r$.

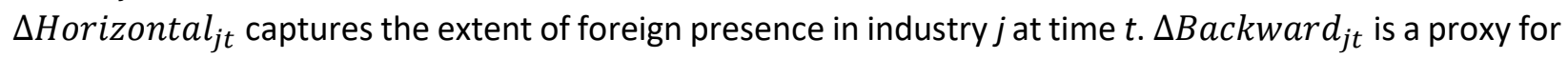
foreign presence in the industries that are being supplied by industry $j$ and $\Delta$ Forward $_{j t}$ captures the share of output in the supplying industry produced by foreign firms. $\Delta \log$ Demand $_{j t}$ is defined as a log change in the demand for intermediates produced by industry $j$, and $\Delta H H I_{j t}$ measures a change in the market concentration in industry $j . \gamma_{j t}$ and $\sigma_{j t}$ are industry-time and region-time fixed effects, respectively. $\varepsilon_{i j r t}$ is the error term. Industries are defined according to the NACE 4-digit level and regions are defined as districts in Serbia. The regressions are run for domestic firms only and standard errors are clustered according to NACE 2-digit levels. Heterogeneity is examined by firm size, the industry's technology level, and type of industry.

The calculation of FDI spillovers is based on Javorcik (2004). Horizontal FDI is measured as the sum of foreign firms' output in each industry-region-year over the total output in that industry, region, and year:

$$
\text { Horizontal }_{j r t}=\frac{\sum_{i} F D I_{i j r t} \times Y_{i j r t}}{\sum_{i j r t} Y_{i j r t}} .
$$

$F D I_{i j r t}$ is an indicator for whether firm $i$ is a foreign firm in industry $j$ in region $r$ for year $t$. In different specifications of the model, a foreign firm is defined as solely foreign, a joint venture, or either. $Y_{i j r t}$ is the output of firm $i$ and $\sum_{i j t} Y_{i j t}$ is the total output of all firms in industry $j$, region $r$ and year $t$. The backward and forward FDI variables are defined as the foreign firms in the buyer and supplier industries. It should be noted that the backward and forward FDI is from the perspective of the foreign firm. Thus, backward FDI is the weighted sum of foreign firms in the downstream industries of the domestic firms, where the weights are the input-output coefficients of the Input-Output tables, and defined as:

$$
\text { Backward }_{j r t}=\sum_{k \neq j} \alpha_{j \rightarrow k} \text { Horizontal }_{k r t}
$$

where $\alpha_{j \rightarrow k}$ is the input-output coefficient that measures the share of outputs of industry $j$ supplied to industry $k$. The forward FDI is the weighted sum of foreign firms in the upstream industries of the domestic firms and is defined as:

$$
\text { Forward }_{j r t}=\sum_{k \neq j} \alpha_{k \rightarrow j} \text { Horizontal }_{k r t}
$$

where $\alpha_{k \rightarrow j}$ is the input-output coefficient that measures the share of inputs of industry $j$ purchased from industry $k$. 


\section{References}

Ackerberg, D. A., Caves, K., \& Frazer, G. (2015). “Identification properties of recent production function estimators." Econometrica, 83(6), 2411-2451.

Bernard, A. B., \& Moxnes, A. (2018). “Networks and trade." Annual Review of Economics, 10, 65-85.

Harrison, A., \& Rodríguez-Clare, A. (2010). "Trade, foreign investment, and industrial policy for developing countries." In Handbook of development economics (Vol. 5, pp. 4039-4214).

Javorcik, B. (2004). "Does foreign direct investment increase the productivity of domestic firms? In search of spillovers through backward linkages." American economic review, 94(3), 605-627.

World Bank (2017). "Evaluating the Serbian Program for Attracting Direct Investments 2006-15: A Microeconometric study." 